\title{
Language Norms of International Treaties
}

\author{
Natalia V. Alontseva ${ }^{1}$, Yury A. Ermoshin \\ Peoples' Friendship University of Russia (RUDN University) \\ 6, Miklukho-Maklaya str., Moscow, Russian Federation, 117198 \\ ${ }^{1}$ alontseva_nv@rudn.university
}

\begin{abstract}
This article discusses features of the implementation of linguistic norms in international treaties. The proposed study has a purpose to identify linguistic means present in international document texts, i.e. treaties that are to fix the agreement that parties achieve with a view to establishing relations and regulating them in future. The research material is 1000 texts of international treaties. The total amount of factual material analyzed is over 6000 pages. Our methodology is based on the works by domestic and foreign authors on general theory of speech activity, laws of perception and understanding of speech, and the peculiarities of the generation of a statement, translation theory, and international law. One of the most important means of expressing information in a text is its lexical composition. International treaties texts comprise different types of vocabulary (common, terminological, specialized, etc.) that performs text- and style forming functions. From the point of view of grammar, compiling international treaties involves using particular grammatical forms and categories, syntactic structures and types of phrases. The essence of international treaties texts implies the presence of special clichés of a business style. In the preparation and editing of international treaties, the adequate use of appropriate vocabulary and grammatical means leads to a reduction of ambiguities and discrepancies in the texts of these documents.
\end{abstract}

Key words: international treaty, language norm, terminological vocabulary, special vocabulary, syntax, phraseology, cliché, English, Russian

\section{Article history:}

Received: 20.05.2020

Accepted: 31.05.2020

\section{For citation:}

Alontseva, N.V. \& Ermoshin, Y.A. (2020). Language Norms of International Treaties. RUDN Journal of Language Studies, Semiotics and Semantics, 11 (3), 532-544. doi: 10.22363/23132299-2020-11-3-532-544

(C) Алонцева Н.В., Еромошин Ю.А., 2020.

This work is licensed under a Creative Commons Attribution 4.0 International License https://creativecommons.org/licenses/by/4.0/ 


\title{
Языковые нормы международных договоров
}

\author{
Н.В. Алонцева ${ }^{1}$, Ю.А. Ермошин \\ Российский университет дружбы народов \\ ул. Миклухо-Маклая, 6, г. Москва, Российская Федерация, 117198 \\ 1alontseva_nv@rudn.university
}

\begin{abstract}
В предлагаемой статье обсуждаются особенности реализации языковых норм в международных договорах. Данная статья ставит цель - определить, какие лингвистические средства, присутствующие в текстах международной документации, т.е. в международных договорах, служат для того, чтобы зафиксировать заключаемые международные соглашения об установлении отношений и об их будущем регулировании. Материал исследования составили 1000 текстов международных договоров. Общий объем проанализированного фактического материала свыше 6000 страниц. Методологическую основу исследования составили труды отечественных и зарубежных авторов по общей теории речевой деятельности, закономерностям восприятия и понимания речи и особенностям порождения высказывания, теории перевода, международному праву. Одним из важных способов предоставления информации в тексте является его лексическая композиция. Тексты международных договоров включают в себя различные виды лексики (общеупотребительная, терминологическая, специализированная и др.), которая выполняет тексто- и стилеобразующую функции. С точки зрения грамматики составление текстов международных договоров требует использования особых грамматических форм и категорий, синтаксических структур и видов словосочетаний. Природа текстов международных договоров подразумевает присутствие в них специализированных клише, присущих деловому стилю коммуникации. При подготовке и составлении текстов международных договоров адекватное использование соответствующей лексики и грамматических средств приводит к уменьшению неясностей и разночтений текстов этих документов.
\end{abstract}

Ключевые слова: международный договор, языковая норма, терминологическая лексика, специальная лексика, синтаксис, фразеология, клише, английский язык, русский язык

\section{История статьи:}

Дата поступления: 20.05.2020

Дата приема в печать: 31.05 .2020

\section{Для цитирования:}

Alontseva N.V., Ermoshin Y.A. Language Norms of International Treaties // Вестник Российского университета дружбы народов. Серия: Теория языка. Семиотика. Семантика. 2020. Т. 11. no 3. 532-544. doi: 10.22363/2313-2299-2020-11-3-532-544

\section{Introduction}

The sphere of official international communication implies using official business style, i.e. the style inherent to diplomatic, clerical and legislative documentation. Official international documents are characterized by their conciseness, standardization, accuracy and consistency. As a matter of fact, there are international standards to follow while compiling them. Official international documents include: business correspondence, agreement, contracts, decrees, legislative acts and many others. 
Official business documents receive standardization and semantic accuracy though thoroughly selected acute words and phrases that in the majority do not require synonyms and fully express the meaning of the notion or phenomenon.

As it is widely known, international documents have a tendency to unification - to be presented in a single, recognized form. As N.Y. Shtreker states, «the unification of documents is to establish uniformity in composition and forms of documents fixing the implementation of functions of the same type. The standardization of documents is a form of legal consolidation of the unification and the level of their binding» [1. P. 92].

T.G. Vinokur, speaking of official business style and ways of its logical presentation, introduces a term 'common usage-style complex' [2. P. 21] and states that the structure of such texts and their composition are organized as aspects and parts of the text are important for textual norms; for language norms, it is typical to limit the possibility of using language units in the document context. At the same time, the links within these texts (lexical, morphological, syntactic) are also of great importance since «only in the interaction do language tools and means of connections make up the common usage-style complex, or expressing plan for the style in question» [3. P. 78].

E.F. Petrishcheva supposes that «international treaties are related to a certain area of social activity that «is in charge of interstate relations within the state» $[4$. P. 54]. Thus, international treaties are to perform the textual means required for the type of official documents.

The very purpose of official documents involves the correct orientation of the text content in the document, therefore, «the interpretation of the content is impossible without studying the internal and external form of the text in terms of its characteristic language means of use, that is, types of language units that reflect specific subject-object relations, spatial and temporal signs» [5].

According to V.V. Kalyuzhnaya, it is possible to emphasize several genres of international documents (their texts). The author proposes «to divide them into:

1) informative documents-genres: memoranda, notes, reports, messages, statements, reviews, working documents of sessions;

2) regulatory documents-genres: charters, constitutions, rules of procedures, conventions, agreements (letters-agreements, notes-agreements), acts, pacts, codes;

3) final documents-genres: resolutions, declarations; 4) summarizing documents-genres: minutes of meetings, summary of the debate» [6. P. 5].

E.F. Petrishcheva suggests that «it is unrealistic to believe that the text of each document should have only its proper, i.e., language-specific means for it» [4. P. 42]. Following her, we would like to accept the idea that only few particular patterns of vocabulary use exist. In the proposed article we suggest pondering on vocabulary and grammatical forms international treaties texts prefer and actively use. 


\section{Methodology}

To conduct the following research with a view to identifying language means and grammar constructions widely used in international documents (treaties) we have selected 1000 texts for analysis, 700 of which belong to resolutions, others introduce conventions. The total amount of factual material analyzed is over 6000 pages. All samples are authentic and were borrowed from Internet sites that have open access.

The methodological basis of the study was the work of domestic and foreign authors on:

a) the general theory of speech activity (A.A. Leontyev [7], T.V. Lipatova [8], A.S. Luria [9], L.V. Shcherba [10], L.S. Vygotsky [11], N.I. Zhinkin [12], I.A. Zimnyaya [13], etc.);

b) the laws of perception and understanding of speech (V.A. Artemov [14], G.A. Miller [15], T.M. Rogozhnikova [16], A.A. Zalevskaya [17], etc.) and the peculiarities of generation of a statement (V.P. Belyanin [18], A.A Leontiev [7], G.A. Miller [15], N.I. Zhinkin [12], etc.);

c) translation theory (L.S. Barkhudarov [19], V.V. Breus [20], T.I. Guskova and G.M. Ziborova [21], I.A. Komissarov [22], R.K. Minyar-Beloruchev [21], A.F. Shiryaev [24], etc.);

d) international law (M.P. Druzhkov, V.I. Evintov [], S. Li [27], I.I. Lukashuk [28], L.N. Mataradze [29], I. Paenson [30], A.N. Talalaev [31], N.N. Ulyanova [32], E. De Vattel [33], etc.).

\section{Language Analysis of International Treaties in the English and Russian Languages}

As we have stated above, our research involved a thorough linguistic analysis, in the result of which we arrived at the conclusions described below.

Treaties introduce commonly used and emotionally coloured book vocabulary:

> commonly used vocabulary: to take into account 'принять во внимание', with a view to 'с целью', in accordance with 'в соответствии с', a great deal of 'много'. It should be noted that commonly used vocabulary prevails over special and terminological vocabulary, the examples of which may be: undersigned plenipotentiaries 'полномочные представители', equally authentic 'равно аутентичный', offer 'оферта', financial contribution 'финансовый вклад', immovable and movable property 'недвижимое и движимое имущество';

$>$ emotionally coloured book vocabulary: Aware that the task of the United Nations to save future generations from the scourge of war requires transformations towards a culture of peace... 'Сознавая, что задача Организации Объединенных Наций избавить грядущие поколения от 
бедствий войны требует перехода к культуре мира...' Emotionally coloured vocabulary is not usually present in treaties, but may be found in some genres. Let us give another example derived from UN Charter: «We the peoples of the United Nations determined to save succeeding generations from the scourge of war, which twice in our lifetime has brought untold sorrow to mankind, and to reaffirm faith in fundamental human rights, in the dignity and worth of the human person, in the equal rights of men and women and of nations large and small .... 'Мы, народы Объединенных Наций, преисполнены решимости избавить грядущие поколения от бедствий войны, дважды в нашей жизни принесшей человечеству невыразимое горе, и вновь утвердить веру в основные права человека, в достоинство и ценность человеческой личности, в равноправие мужчин и женщин и в равенство прав больших и малых наций...'» [37].

The official character of treaties can be reached by using special vocabulary, which leads to differentiation of treaties from other genres and brings in unambiguity to the document. Special vocabulary can be introduced in different groups:

$>$ full and exact name of the document: resolution 'резолюция', declaration 'декларация', etc.;

$>$ name of bodies accepting the international treaty: General Assembly 'Генеральная Ассамблея', Security Council 'Совет Безопасности', etc.;

$>$ vocabulary related to the conclusion of the treaty, its signing, ratification, initiation, entry into force: equally authentic 'равно аутентичные', enter into force 'вступать в силу', etc.;

$>$ introductory words introducing a logical context: acknowledging 'отмечая', bearing in mind 'принимая во внимание', deeply regretting 'выражая глубокое сожаление', etc.

Another type of vocabulary widely used in international treaties is terminological vocabulary. Terms are commonly found in conventions (to a greater extend) charters, resolutions and declarations (in a lesser degree). Terminological vocabulary is rich with scientific and technical terms which appear in international official texts due to numerous agreements in science, i.e. nuclear physics, cybernetics, medicine, environmental protection and others. For example: legal proceedings 'судебное разбирательство', financial resources 'денежные ресурсы', or: «Welcoming also United Nations General Assembly Resolution 51/45 S of 10 December 1996 urging all States to pursue vigorously an effective, legally-binding international agreement to ban the use, stockpiling, production and transfer of anti-personnel landmines.... 'Приветствуя также резолюцию 51/45 S Генеральной Ассамблеи Организации Объединенных Наций от 10 декабря 1996 года, в которой ко всем государствам обращен настоятельный призыв активно работать над эффективным, имеющим обязательную юридическую силу международным соглашением о запрещении применения, накопления запасов, производства и передачи противопехотных наземных мин....'» [38]. 
The tradition of concluding treaties originates from the Middle Ages, consequently, in modern text we observe the use of Latin and French borrowings, for example: inter alia 'среди прочего', ipso jure 'по самому закону', chargé d'affaires 'поверенный в делах', compromis d'arbitrage 'арбитражное соглашение, etc. [34].

The compositional drawing of the resolution genre in English and Russian coincides as a result of the general principle of division, in which the text is divided into two parts: ascertaining and deciding. The existence of ascertaining and operative parts allows changing their correlation in terms of volume, i.e., the parties adopting the resolution may pay more attention to one of the parts than the other.

Let us consider an example of resolution in the English and Russian languages borrowed from an open access site of General Assembly of the United Nations:

53/5 Observer status for the Association of Caribbean States in the General Assembly

Date: 15 October

Adopted without a vote

The General Assembly,

Bearing in mind that the purposes of the Association of Caribbean States, as enunciated in the convention by which it was established, and which has been registered with the Secretariat, are consistent with those of die United Nations,

Considering that, accordingly, it is mutually advantageous to provide for cooperation between the United Nations and the Association of Caribbean States,

Taking note of the desire of the Association of Caribbean States for the establishment of such cooperation,

1. Decides to invite the Association of Caribbean States to participate in the sessions and the work of the General Assembly in the capacity of observer;

2. Requests the Secretary-General to take the necessary action to implement the present resolution.

\section{3/5. Предоставление Ассоциации карибских государств статуса наблюдателя в Генеральной Ассамблее}

\section{Генеральная Ассамблея,}

принимая во внимание, что цели Ассоциации карибских государств, провозглашенные в конвенции, в соответствии с которой она была учреждена и которая была зарегистрирована в Секретариате, соответствуют целям Организации Объединенных Наций,

учитывая, что, таким образом, поддержание сотрудничества между Организацией Объединенных Наций и Ассоциацией карибских государств отвечает их взаимным интересам, 
принимая к сведению желание Ассоциации карибских государств наладить такое сотрудничество,

1) постановляет предложить Ассоциации карибских государств принимать участие в сессиях и работе Генеральной Ассамблеи в качестве наблюдателя;

2) просит Генерального секретаря принять необходимые меры для выполнения настоящей резолюции.

38-е пленарное заседание, 15 октября 1998 года

From the above example, it follows that the resolution is represented by one nominative sentence, the subject of which is at the beginning of the document. Each position of the ascertaining part begins with a new line and is introduced by the circumstance of the mode of action. Operative clauses also begin on a new line and are always introduced by homogeneous predicates. To enhance the reader's attention, it is common to resort to font selection, which facilitates the perception of the document. Usually the subject and first words are highlighted in the ascertaining and operative parts, that is, modifiers - in the ascertaining part and predicates - in the operative part.

Paragraph division is widely used in the drafting of resolutions. Characteristically, the paragraph is part of the whole (part of the sentence participial construction or a homogeneous predicate with words adjacent to it) [6. P. 43]. Paragraphs are separated by a comma or semicolon. Paragraph division as well as font selection makes the text clearer and allows the recipient to selectively consider a particular position of the document.

In this type of documents, there are standard initial words established by many years of practice that perform a specific function inherent only to these documents. We can make a list of such words and phrases that each time, regardless of context, will have the same equivalent in another language, for example: having examined 'рассмотрев', condemning 'осуждая', hoping 'выражая надежду'. Sometimes a number of English synonyms has one option in Russian, or, conversely, a number of Russian synonyms corresponds to one English option, for example: принимая во внимание 'bearing in mind/having in mind/keeping in mind', affirming 'заявляя/ утверждая/ подтверждая /поддерживая'.

The following words are used in the role of the initial words of the ascertaining part: present participles (affirming, appreciating, believing); adjectives (cognizant, conscious, desirous); past participles with and without preposition (alarmed by, concerned, convinced); perfect participle construction (having examined).

After analyzing a number of authentic resolutions, we can conclude that all of these initial units correspond to the participles in the Russian text, in the syntactic plan - to modifiers of manner. For instance: Совет Безопасности, подтверждая свои предыдущчие резолющчи по Афганистану, в частности, 
свои резолюичии 1378 (2001) от 14 ноября 2001 года и 1383 (2001) от 6 декабря 2001 года, признавая, что ответственность за обеспечение безопасности и правопорядка на всей территории страны лежит на самих афганцах....

The initial words - present participles of active voice may also comprise the following groups:

$>$ Participle I and Adverb: Appreciating highly the important role that Nepal has played as the host nation of the headquarters of the Regional Centre... 'Высоко оценивая важную роль, которую играл Непал как государство, разместившее у себя штаб-квартиру Регионального центра...'

$>$ Participle I and $\mathrm{N}$ and preposition: Affirming also the illegality of the Israeli settlements in the territory occupied since 1967 and of Israeli actions aimed at changing the status of Jerusalem... 'Подтверждая также незаконный характер израильских поселений на территории, оккупированной с 1967 года, и израильских действий, направленных на изменение статуса Иерусалима...'

Sometimes the presence of an adverb, which is a modifier of manner, in front of the participle requires a different equivalent in Russian, for example: Concerned about the threats posed by the proliferation of nuclear weapons to the security and stability of the Middle East region. 'Будучи встревожена угрозами, которые распространение ядерного оружия создает для безопасности и стабильности региона Ближнего Востока'.

The initial words - adjectives. English adjectives in the ascertaining part correspond to the Russian participles, and not the adjectives: conscious 'сознавая': Conscious that the problem of ocean space are closely interrelated and need to be considered as a whole... 'Сознавая, что проблемы океанских акваторий тесно взаимосвязаны и их необходимо рассматривать как единое целое...'

The initial words - past participles. These initial words show the attitude of the body adopting the resolution to this state of affairs, which should be taken into account when drawing up resolutions and when translating them. It is important that in general past participles can have several correspondences, but in this type of documents only one type is used assigned to them: concerned, but not being concerned, in Russian будучи встревожена, but not встревожена: Concerned about the threats posed by the proliferation of nuclear weapons to the security and stability of the Middle East region... 'Будучи встревожена угрозами, которые распространение ядерного оружия создает для безопасности и стабильности региона Ближнего Востока...'.

The initial words - constructions with perfect participles. The use of this construction designates an action that occurred in the past, and in the present it is stated as a fact: Having considered the report of the Secretary - General on emergency economic assistance to the Comoros... 'Рассмотрев доклад Генерального секретаря о чрезвычайной экономической помощи Коморским Островам...'. 
Each new thought in the operative part begins with a new line and is introduced by a verb in the third person singular (less often - plural). We have identified 100 stylistically neutral verbs used in operative part of resolutions (decides 'постановляет', declares accordingly 'объявляет соответственно'), which either express approval (welcomes 'приветствует, принимает', adopts 'одобряет'), or have a connotation tone (condemns 'осуждает'). All verbs form initial groups in the text, and the number of these structural groups is limited. Let us list them:

1. Verb + noun + infinitive:

Invites the Chairman to keep the Council informed on developments in the peace process. 'Просит Председателя информировать Совет о событиях в рамках мирного процесса'.

2. Verb + infinitive:

Decides to extend the mandate of UNPROFOR. 'Постановляет продлить мандат COOHO'.

3. Verb + subordinate clause:

Demands that all sides refrain from laying mines, in particular in those areas now under their control, which under the Peace Agreement will be transferred to another party. 'Требует, чтобы все стороны воздерживались от установки мин, в частности, в районах, находящихся в настоящее время под их контролем, которые по условиям Мирного соглашения будут переданы другой стороне'.

4. Verb + noun:

Welcomes the report of the Secretary-General of 24 November 1995 as a useful framework for his ongoing efforts aimed at accelerating and completing the identification process. 'Приветствует доклад Генерального секретаря от 24 ноября 1995 года в качестве полезных рамок для предпринимаемых им в настоящее время усилий, направленных на ускорение и завершение процесса идентификации'.

International treaties style involves using certain specific words, phrases, and sentences inherent to this genre, e.g. a party 'сторона', whereas 'принимая во внимание', etc. V.M. Boguslavsky suggests regarding 'business standards' to trace their performance [35. P. 35]. Business standards vocabulary typical of international official communication comprises 'ready-made word stamps' [36. P. 106-114].

Key business standards may be classified as follows:

1. Nominative business standards represented by the following groups:

a) Noun + Noun: State Party 'государство-участник';

b) Noun + preposition + Noun: instrument of accession 'акт о присоединении', the date of deposit 'в день сдачи';

c) Adjective + Noun: human rights 'права человека', fundamental freedoms 'основные свободы'.

2. Verbal business standards represented as follows: 
a) Verb + Noun: to make reservation 'делать оговорки', to inform the Secretary-General 'уведомлять Генерального Секретаря';

b) Verb + preposition + Noun: to accede to a convention 'присоединиться к конвенции'.

3. Phrase business standards. Mainly used at the beginning of documents and in final articles, e.g. have agreed as follows 'согласились о нижеследующем', the present Convention shall enter into force 'настоящая Конвенция вступает в силу'.

Analyzing the language of conventions, we can conclude that the number of business standards in them is limited, and their use relates mainly to the preambles and final articles of the conventions.

\section{Conclusion}

1. International treaties texts are strictly regulated by the nature and essence of the document and also the language means used to deliver information to international partners or parties. Official international documents including international treaties texts are characterized as concise, standardized, accurate and consistent.

2. A significant component of text organization international treaties use is their lexical composition, i.e. international treaties imply commonly used, terminological, special and emotionally coloured book (in a lesser degree) vocabulary.

3. Vocabulary performs text-forming and style-forming functions. The grammatical side of text formatting is noted by the consolidation of certain grammatical categories and forms, certain types of phrases and syntactic structures (voice, gerundial and participial forms and constructions, infinitives and infinitive constructions, etc.).

4. Texts of international treaties also involve phrases related to the border zone between syntax and phraseology and reflecting special clichés of a business style. The choice and use of vocabulary and grammatical means of official business style lead to a reduction of ambiguities and discrepancies in the texts of international treaties.

5. Certain types of international documents use business standards. Despite the fact that their number is limited, their use relates to preambles and final articles of the conventions, with makes them standardized and respond to the objective set.

\section{References}

1. Shtreker, N.Yu. (2003). Russian language and culture of speech. Moscow: UNITY-DANA. (In Russ.).

2. Vinokur, T.G. (1987). The use of language as the main subject of stylistics In Stylistics of the Russian language: Genre-communicative. aspect of the style of the text, V.N. Vinogradova, T.G. Vinokur, L.I. Eremin and others; A.N. Kozhin (Ed.). Moscow: Nauka. pp. 18-27. (In Russ.). 
3. Barlas, L.G. (1978). Russian language. Stylistics. Moscow: Prosveshhenie. (In Russ.).

4. Petrishcheva, E.F. (1987). Functional and stylistic differentiation of speech In Stylistics of Russian language. Moscow. (In Russ.).

5. Yartseva, V.I. (1981). Contrast grammar. Moscow: Nauka. (In Russ.).

6. Kalyuzhnaya, V.V. (1982). Style of English documents of international organizations. Kiev: Naukova dumka. (In Russ.).

7. Leontyev, A.A. (1999). Fundamentals of Psycholinguistics. Moscow: Nauka. (In Russ.).

8. Lipatova, T.V. (2015). The formation of meaning and functional motivation of language units' semantics. RUDN Journal of Language Studies, Semiotics and Semantics, 3, 17-25. (In Russ.).

9. Luria, A.R. (1998). Language and consciousness. Moscow: Moscow Publishing House University. (In Russ.).

10. Shcherba, L.V. (1974). Language system and language activity. Leningrad: Nauka. (In Russ.).

11. Vygotsky, L.S. (1934). Thinking and Speech. Moscow—Leningrad: Sotsekgiz. (In Russ.).

12. Zhinkin, N.I. (1964). About code transitions in internal speech. Topics in the study of language, 6, 26-38. (In Russ.).

13. Zimnyaya, I.A. (2001). Linguopsychology of speech activity. Moscow-Voronezh: NPO MODEK. (In Russ.).

14. Artemov, V.A. (1969). Psychology of teaching foreign languages. Moscow: Prosveshhenie. (In Russ.).

15. Miller, G.A. \& Johnson-Laird, P.N. (1976). Language and perception. Cambridge: Harvard Univ. Press.

16. Rogozhnikova, T.M. (1988). The mechanisms of the functioning of the word in the individual consciousness: their specificity and sequence of formation In Psycholinguistic studies of the meaning of the word and understanding of the text: Interuniversity. topics Sat scientific tr. I Kalinin. gos. un-t; A.A. Zalevskaya (Ed.). Kalinin. pp. 15-22.

17. Zalevskaya, A.A. (1982). Psycholinguistic problems of the semantics of the word. Kalinin. (In Russ.).

18. Belyanin, V.P. (2001). Introduction to Psycholinguistics. Moscow: CheRo. (In Russ.).

19. Barkhudarov, L.S. (1975). Language and translation: General and private translation theory. Moscow: Mezhdunarodnye otnoshenija. (In Russ.).

20. Breus, E.V. (2002). Fundamentals of the theory and practice of translation from Russian into English. Moscow: Publishing house of the University RAE. (In Russ.).

21. Guskova, T.I. \& Ziborova, G.M. (2000). Difficulties in translating a socio-political text from English into Russian. Moscow: Rosspan. (In Russ.).

22. Komissarov, V.N. (1990). Translation Theory: Linguistic aspects: Moscow: Vysshaja shkola. (In Russ.).

23. Minyar-Beloruchev, R.K. (1991). About the principles of teaching foreign languages In General methodology of teaching foreign languages, A.A. Leontiev (Introduc.). Moscow: Russkij jazyk. pp. 43-53. (In Russ.).

24. Shiryaev, A.F. Simultaneous translation. The activities of the simultaneous translator and the methodology of teaching simultaneous translation [Electronic resource]. URL: http://sch-yuri.narod.ru/transltn/shir.htm (accessed: 04.04.2020). (In Russ.).

25. Druzhkov, M.P. (1986). The conclusion of international treaties within and under the auspices of international organizations. Kiev: Naukova dumka. (In Russ.).

26. Evintov, V.I. (1981). Multilingual treaties in modern international law. Kiev: Naukova dumka. (In Russ.).

27. Shuangling, Li (2019). Communicative significance of vague language: a diachronic corpusbased study of legislative texts. English for Specific Purposes, 53, 104-117.

28. Lukashuk, I.I. (2001). Form of international treaties. Moscow: Spark, 2001. (In Russ.).

29. Mataradze, L.N. (1971). Form of international treaty. Tbilisi: Metzniereba. (In Russ.).

30. Paenson, I. (1983). Manual of the Terminology of Public International Law (peace) and International Organizations. Brussels.

31. Talalaev, A.N. (1980). The law of international treaties. Moscow: Mezhdunarodnye otnoshenija. (In Russ.). 
32. Ulyanova, N.N. (1981). General multilateral treaties in modern international relations: Some issues. theories. Kiev: Naukova dumka. (In Russ.).

33. De Vattel, E. (1960). The law of peoples or the principles of natural law applicable to the conduct and affairs of nations and sovereigns. Moscow. (In Russ.).

34. Alontseva, N.V. \& Tomashevich, S.B. (2012). Textual and linguistic norms of official documents. Russian Journal of Linguistics, 1, 33-38. (In Russ.).

35. Boguslavsky, V.M. (1968). In defense of the business stamp. Russkaya Rech', 6, 33-38. (In Russ.).

36. Rosen, E.V. (1961). About some cliches of German spoken language. Foreign language at school, 4, 106-114. (In Russ.).

37. URL: https://www.un.org/ru/sections/un-charter/preamble/index.html (accessed: 07.04.2020).

38. URL: https://www.un.org/ru/documents/decl_conv/conventions/mines_convention.shtml (accessed: 07.04.2020).

39. URL: https://www.un.org/en/ga/74/resolutions.shtml (accessed: 07.04.2020).

\section{Библиографический список}

1. Штрекер Н.Ю. Русский язык и культура речи: Учеб. пособие. М.: ЮНИТИ-ДАНА, 2003.

2. Винокур Т.Г. Употребление языка как основной предмет стилистики // Стилистика русского языка: Жанрово-коммуникативный аспект стилистики текста / В.Н. Виноградова, Т.Г. Винокур, Л.И. Еремина и др.; Отв. ред. А.Н. Кожин. М.: Наука, 1987. С. $18-27$.

3. Барлас Л.Г. Русский язык. Стилистика: Пособие для учителей. М.: Просвещение, 1978.

4. Петрищева Е.Ф. Функциональная и стилистическая дифференциация речи // Стилистика русского языка. М., 1987.

5. Яриева В.И. Контрастивная грамматика. М.: Наука, 1981.

6. Калюжная B.B. Стиль англоязычных документов международных организаций. Киев: Наук. думка, 1982.

7. Леонтьев А.А. Основы психолингвистики: Учеб. для вузов по специальности «Психология». М.: Смысл, 1999.

8. Липатова T.B. О приоритетах системной лингвистики // Вестник Вестник Российского университета дружбы народов. Серия: Теория языка. Семиотика. Семантика. 2015. no 3. C. $17-25$.

9. Лурия А.Р. Язык и сознание: Учеб. пособие. М.: Изд-во Моск. ун-та, 1998.

10. Щерба Л.В. Языковая система и языковая деятельность. Л.: Наука, 1974.

11. Выготский Л.С. Мышление и речь: Психол. исслед. М.; Л.: Соцэкгиз, 1934.

12. Жинкин Н.И. О кодовых переходах во внутренней речи // Вопросы языкознания. 1964. no 6. С. $26-38$.

13. Зимняя И.А. Лингвопсихология речевой деятельности. М.: Московский психол.-соц. ин-т; Воронеж: НПО “МОДЭК”, 2001.

14. Артемов B.A. Психология обучения иностранным языкам. М.: Просвещение, 1969.

15. Miller G.A., Johnson-Laird P.N. Language and perception. Cambridge: Harvard Univ. Press, 1976.

16. Рогожникова T.M. Механизмы функционирования слова в индивидуальном сознании: их специфика и последовательность становления // Психолингвистические исследования значения слова и понимания текста: Межвуз. темат. сб. научн. тр. / Калинин. гос. ун-т; Отв. ред. А.А. Залевская. Калинин, 1988. С. 15-22.

17. Залевская А.А. Психолингвистические проблемы семантики слова. Калинин, 1982.

18. Белянин В.П. Введение в психолингвистику. М.: ЧеРо, 2001.

19. Бархударов Л.С. Язык и перевод: Вопр. общ. и частной теории перевода. М.: Междунар. отношения, 1975.

20. Бреус E.B. Основы теории и практики перевода с русского языка на английский: Учеб. пособие. М.: Изд-во ун-та Рес. акад. образования, 2002.

21. Гуськова Т.И., Зиборова Г.М. Трудности перевода общественно-политического текста с английского языка на русский: Учеб. пособие для ин-тов и фак. иностр. яз. М.: Росспэн, 2000. 
22. Комиссаров B.Н. Теория перевода: Лингвист. аспекты: Учеб. для ин-тов и фак. иностр. яз. М.: Высш. шк., 1990.

23. Миньяр-Белоручев Р.К. О принципах обучения иностранным языкам // Общая методика обучения иностранным языкам: Хрестоматия / Предисл. А.А. Леонтьева. М.: Рус. яз., 1991. C. $43-53$.

24. Ширяев А.Ф. Синхронный перевод. Деятельность синхронного переводчика и методика преподавания синхронного перевода [Электронный ресурc]. Режим доступа: http://schyuri.narod.ru/transltn/shir.htm (дата обращения: 07.04.2020).

25. Дружков М.П. Заключение международных договоров в рамках и под эгидой международных организаций. Киев: Наук. думка, 1986.

26. Евинтов В.И. Многоязычные договоры в современном международном праве. Киев: Наук. думка, 1981.

27. Shuangling Li Communicative significance of vague language: A diachronic corpus-based study of legislative texts // English for Specific Purposes. 2019. no 53. pp. 104-117.

28. Лукашук И.И. Форма международных договоров: Учеб.-практ. пособие. М.: Спарк, 2001.

29. Матарадзе Л.Н. Форма международного договора. Тбилиси: Мецниереба, 1971.

30. Paenson I. Manual of the Terminology of Public International Law (peace) and International Organizations. Brussels, 1983.

31. Талалаев А.Н. Право международных договоров. М.: Междунар. отношения, 1980.

32. Ульянова Н.Н. Общие многосторонние договоры в современных международных отношениях: Некоторые вопр. теории. Киев: Наук. думка, 1981.

33. Ваттель Э. Право народов или принципы естественного права, применяемые к поведению и делам наций и суверенов. М., 1960.

34. Алонцева Н.В., Томашевич С.Б. Текстовые и языковые нормы официальных документов // Вестник Российского университета дружбы народов. Серия: Лингвистика. 2012. no 1. C. 33-38.

35. Богуславский В.М. В защиту делового штампа // Русская речь. 1968. nо 6. С. 33-38.

36. Розен E.B. О некоторых клише немецкой устной речи // Иностранный язык в школе. 1961. no 4. C. 106-114.

37. Режим доступа: https://www.un.org/ru/sections/un-charter/preamble/index.html (дата общения: 07.04.2020).

38. Режим доступа: https://www.un.org/ru/documents/decl_conv/conventions/mines_convention.shtml (дата общения: 07.04.2020).

39. Режим доступа: https://www.un.org/en/ga/74/resolutions.shtml (дата общения: 07.04.2020).

\section{Information about the authors:}

Natalia V. Alontseva, Associate professor of the department of foreign languages, RUDN University; academic interests: pragmatics, discourse analysis, methods of teaching foreign languages; e-mail: alontseva_nv@rudn.university.

Yury A. Ermoshin, Associate professor of the department of foreign languages, $\mathrm{PhD}$ in Pedagogy, RUDN University; academic interests: pragmatics, discourse analysis, methods of teaching foreign languages; e-mail: ermoshin_yua@ rudn.university.

\section{Сведения об авторах:}

Алониева Наталья Владимировна, доцент, доцент кафедры иностранных языков филологического факультета РУДН; научные интересы: прагматика, дискурсивный анализ, методика преподавания иностранных языков; e-mail: alontseva_nv@rudn.university.

Ермошин Юрий Анатольевич, доцент кафедры иностранных языков филологического факультета РУДН; научные интересы: прагматика, дискурсивный анализ, методика преподавания иностранных языков; e-mail: ermoshin-yua@ rudn.university. 